\title{
Self-Sustainability of Farming Community through Promotion of Organic Agriculture: A Case Study of KVK, Bagalkot, India
}

\author{
Mouneshwari R. Kammar*, A.P. Biradar, Arjun Sulagitti and S. Sudha \\ ICAR-Krishi Vigyan Kendra, Bagalkot, Karnataka, India \\ University of Agricultural Sciences, Dharwad, Karnataka, India \\ *Corresponding author
}

\section{A B S T R A C T}

It is said that, organic agriculture is the future of Indian Agriculture. With the impact of green revolution on soils and water, we are in the fear of facing soil degradation. This paper is aimed to throw lights on the experiences of Krishi Vigyan Kendra (KVK),

\section{Keywords}

Metarrhizium, Pseudomonas and Trichoderma

\section{Article Info}

Accepted: 26 August 2018 Available Online: 10 September 2018 Bagalkot, Karnataka, India in the production and sale of organic inputs. Inputs such as vermicompost, earthworms, vermiwash, azolla, Metarrhizium, Pseudomonas and Trichoderma promotion of apiculture by demonstrating honey bee colonies are the major components, which $\mathrm{KVK}$ is producing and selling. In the present paper the year wise production and sales of organic inputs are taken into account to derive the total area and economic impact thereof. The receipts of produce sold at laboratories served as the source of information to the study. The results indicate that, the sale of inputs is on rise, so also the farmers who are adopting these technologies in their own field are also more. People are approaching KVK for these technologies. To increase the production of organic inputs $\mathrm{KVK}$, Bagalkot is imparting the technologies of Vermicompost production (Biradar, 2006). The follow up of the results of the training conducted in this regard also showed that, nearly 80 per cent of the trainees have adopted these techniques of producing these inputs. Though the economics are not comparable, the quality of the soil matters in this regard. Hence more comprehensive studies are required to analyze the impact of these technologies on the soil quality characteristics.

\section{Introduction}

KVK Bagalkot was sanctioned by the Indian Council of Agriculture during the year 2005, and started functioning under the aegis of University of Agricultural Sciences, Dharwad. Since then, it has contributed in its own way to the development of district agriculture. A special feature of this district is that, it is blessed with two irrigation, hence there is large scope and potentiality for the development of agriculture. There is a total of 50 lakh ha of net sown area for agriculture, of which 50 per cent irrigation. Major crop of the district being sugarcane, consumes 50 per cent of water and is cultivated in an area of 20 percent of the cultivated area. Though very recently there is increase in area under redgram and other crops, people opt for sugarcane i.e., a cash crop. Parallel to this there is increase in the use of pesticides and insecticides. 
The days are not far from becoming the lands converted into unproductive ones as the heavy irrigation accompanied with high dose of pesticide, weedicides and fertilizer application. Along with soils becoming problematic, there may also be stagnation or reduction in yield levels. This fact has been established through many studies, and declining soil fertility of Punjab is a live example for all of us. According to a recent report it has been established that, the unsustainable management practices in Punjab have damaged soil fertility and health, leading to promotion of chemical fertilizers which too is inefficient to the desirable level, according to the Soil Fertility Atlas recently published by the Food and Agriculture Organisation (FAO) of the United Nations. Keeping this view in mind KVK Bagalkot is involved in demonstration, production of and promotion of organic inputs.

On an average earthworm presence in agro ecosystems leads to a $25 \%$ increase in crop yield and a $23 \%$ increase in above ground biomass. The magnitude of these effects depends on presence of crop residue, earthworm density and type and rate of fertilization. The positive effects of earthworms become larger when more residues is returned to the soil, but disappear when soil nitrogen availability is high. This suggests that earthworms stimulate plant growth predominantly through releasing nitrogen locked away in residue and soil organic matter (Willem J. et al., 2014).

\section{Materials and Methods}

This paper exploits the secondary data on production and sale of organic inputs and bioagents maintained at Krishi Vigyan Kendra, Bagalkot for two years. Major inputs are vermicompost, earthworms, vermiwash, Metarrhizium, Pseudomonas and Trichoderma. Production of these inputs since
2016-17 has been taken into consideration for analysis. The procedure mentioned by Biradar et al., (2007) and Biradar and Shaila (2005) were followed for the production vermiculture related products. This paper analyses the total organic inputs produced by $\mathrm{KVK}$ and its impact on district agriculture. For the convenience of analysis, the products have been divided into two groups viz., 1. Vermiculture related products and 2 . Biocontrol agents. The records of trainings conducted by Krishi Vigyan Kendra were also served as the source of information. Simple frequency and percentages were calculated to arrive at conclusion.

\section{Results and Discussion}

This table 1 indicates the total production of vermicompost and other related products produced and sold to the farmers in this district. Another important tool in the vermiculturing is training related to vermicomposting. There are regular schedule of trainings are being conducted to the farmers in the preparation of vermicompost, vermiwash and earthworms. There are totally 10-15 trainings conducted in the area of organic agriculture. During the year 201617there was a paid training was organized on Dairying and vermiculture exclusively. All the trainees who have undergone this training are practicing the organic agriculture. The impact of this training was analyzed by getting the feedback through telephone interview. The results are as follows

One kilogram of worms numbering about 600 to 1000 can convert 25 to $45 \mathrm{~kg}$ of wet waste per week. The compost recovery would be around $25 \mathrm{~kg}$ per week under well managed conditions.

One kilogram of earthworms produces a minimum of 2000 and a maximum of 5000 cocoons per week. The viability of cocoons 
will be around 60 per cent and incubation period is about 2 weeks. However with preservation, the viability can be retained upto 3 months. They become sexually matured in about 6 to 8 weeks. Each matured earthworm lays eggs at 7 to 10 days interval and with the period of 12 months, each earthworm produces 247 worms.

The young worms take about 90 days to attain maturity and reproduction capacity. They have tremendous rate of growth if the conditions are congenial and feed is good. About $1 \mathrm{~kg}$ biomass equivalent earthworms can become $20 \mathrm{~kg}$ in 4 months and $200 \mathrm{kgs}$ in another 4 months (Anon. 2017 and Kumar, 2018). A general thumb rule is that, Earth worms eat half of their body weight. Hence, if we apply the rule of conversion, the calculation goes the following way (Table 2-4).

One kilogram of earth worm gets converted to $20 \mathrm{~kg}$ in 4 months and $200 \mathrm{~kg}$ in 8 months

During 2016-17: - $150 \mathrm{~kg}$ become $3000 \mathrm{~kg}$ in 4 months and 30,000 $\mathrm{kg}$ in another 4 months

Table.1 Production of vermicompost and related products at KVK, Bagalkot

\begin{tabular}{|c|c|c|c|c|c|c|}
\hline Particulars & \multicolumn{2}{|c|}{$2016-17$} & \multicolumn{2}{c|}{$2017-18$} & Total & value (Rs.) \\
\hline Vermicompost (q) & qty & value (Rs.) & qty & value (Rs.) & & \\
\hline Vermiwash (lit) & 873 & 78070 & 211.5 & 135360 & 354.5 & 226880 \\
\hline Live earthworms (kg) & 151 & 38800 & 233 & 62025 & 1840 & 156400 \\
\hline
\end{tabular}

Table.2 Quantity of the vermicompost produced by the trainees at their fields

\begin{tabular}{|l|l|l|l|l|l|}
\hline $\begin{array}{l}\text { S. } \\
\text { No. }\end{array}$ & Name of the farmer & Qty (Tones) & $\begin{array}{l}\text { Amount } \\
\text { generated } \\
\text { (Rs.) }\end{array}$ & $\begin{array}{l}\text { Area under } \\
\text { organic } \\
\text { farming (Ac) }\end{array}$ & $\begin{array}{l}\text { Amount saved } \\
\text { through } \\
\text { fertilizers (Rs.) }\end{array}$ \\
\hline $\mathbf{1}$ & Vinod R Katwa & 10 & 64000 & 3 & 6000 \\
\hline 2 & Chandrashekar S vadeyar & 18 & 115200 & 12 & 24000 \\
\hline 3 & Shivanadan Choudari & 12 & 76800 & 6 & 12000 \\
\hline 4 & Pratap B Chandanshu & 15 & 96000 & 15 & 30000 \\
\hline 5 & Dhariyappa M Siddapur & 16 & 102400 & 10 & 20000 \\
\hline 6 & Laxamana R Kanabur & 8 & 51200 & 4 & 8000 \\
\hline 7 & S. R. Horatti & 10 & 64000 & 6 & 12000 \\
\hline 8 & Basavaraj Muttappa Gaddi & 15 & 96000 & 10 & 20000 \\
\hline & TOTAL & 104 & 665600 & 66 & 132000 \\
\hline
\end{tabular}

Table.3 The composition of vermicompost

\begin{tabular}{|l|l|l|l|l|l|}
\hline \multicolumn{2}{|l|}{ Macronutrients $(\%)$} & \multicolumn{2}{|c|}{ Micronutrients(mg/kg) } & \multicolumn{2}{|l|}{ Microbial compositions/g } \\
\hline $\mathbf{N}$ & 1.10 & $\mathrm{Cu}$ & 52.0 & Fungi & $2.60 \times 10^{4}$ \\
\hline $\mathrm{P}$ & 0.86 & $\mathrm{Fe}$ & 930.0 & Bacterial & $11.37 \times 10^{7}$ \\
\hline $\mathrm{K}$ & 0.98 & $\mathrm{Zn}$ & 186.60 & Actinomycetes & $10.43 \times 10^{4}$ \\
\hline
\end{tabular}


Table.4 Production of Bio-agents during the year 2016-17 and 2017-18 at KVK Bagalkot

\begin{tabular}{|c|c|c|c|c|c|c|}
\hline & \multicolumn{2}{|c|}{$2016-17$} & \multicolumn{2}{c|}{ 2017-18 } & \multicolumn{2}{c|}{$\begin{array}{c}\text { Total } \\
\text { value }\end{array}$} \\
\hline & qty(kg) & value (Rs.) & qty(kg) & value (Rs.) & quantity(Kg) & (Rs.) \\
\hline Trichoderma & 564 & 57120 & 372 & 48360 & 936 & 121680 \\
\hline Metarhizium & 379 & 76100 & 508 & 127000 & 887 & 221750 \\
\hline Pseudomonas & 385 & 39650 & 440 & 66000 & 825 & 123750 \\
\hline
\end{tabular}

\section{Trichoderma harzianum}

\begin{tabular}{|c|c|c|c|c|c|}
\hline Crops & $\begin{array}{c}\text { No. of } \\
\text { Farmers } \\
\text { benefitted }\end{array}$ & $\begin{array}{c}\text { Yield of the } \\
\text { crop with } \\
\text { disease(t/ac) }\end{array}$ & $\begin{array}{r}\text { Yield of the } \\
\text { crop without } \\
\text { disease }\end{array}$ & $\begin{array}{c}\text { Savings/ha } \\
\text { the district } \\
\text { economy }\end{array}$ \\
\hline Banana & 30 & 18.48 & 24 & 4416 & $5,51,116$ \\
\hline Watermelon & 80 & 55.20 & 60 & 3840 & $4,79,232$ \\
\hline Onion & 200 & 15.30 & 18 & 2700 & $3,36,960$ \\
\hline
\end{tabular}

Price of Trichoderma harzianum is Rs. 130/kg. Recommended for seed treatment and soil borne diseases in all crops @ $7.5 \mathrm{~kg} / \mathrm{ha}$.

Area covered (ha): 124.8

\section{Metarhizium anisopliae}

\begin{tabular}{|l|l|l|l|l|l|}
\hline Crop & $\begin{array}{l}\text { No. of } \\
\text { Farmers } \\
\text { benefitted }\end{array}$ & $\begin{array}{l}\text { Yield of the } \\
\text { crop with } \\
\text { infestation }\end{array}$ & $\begin{array}{l}\text { Yield of the crop } \\
\text { without } \\
\text { infestation }\end{array}$ & Savings/ha & $\begin{array}{l}\text { Savings to the } \\
\text { district economy }\end{array}$ \\
\hline Sugarcane & 300 & $105 \mathrm{t} / \mathrm{ha}$ & $139.58 \mathrm{t} / \mathrm{ha}$ & 48257 & 3424316 \\
\hline
\end{tabular}

Price of Metarhizium anisopliae is Rs. 250/kg. Recommended for Root grub management in sugarcane @ 12.5kg/ha. Area under sugarcane is 1 lakh ha,

Area covered with Metarhizium: 70.96

\section{Pseudomonas fluorescens}

\begin{tabular}{|l|l|l|l|l|l|l|}
\hline Crop & $\begin{array}{l}\text { Area } \\
\text { under } \\
\text { crop (ha) }\end{array}$ & $\begin{array}{l}\text { No. of } \\
\text { Farmers } \\
\text { benefitted }\end{array}$ & $\begin{array}{l}\text { Yield of the } \\
\text { crop with } \\
\text { disease }\end{array}$ & $\begin{array}{l}\text { Yield of the } \\
\text { crop without } \\
\text { disease }\end{array}$ & $\begin{array}{l}\text { Savings/ } \\
\text { ha }\end{array}$ & Economics \\
\hline Pomegranate & 2298 & 200 & $8.16 \mathrm{t} / \mathrm{ha}$ & $10.89 \mathrm{t} / \mathrm{ha}$ & $2,73,000$ & $3,00,30,000$ \\
\hline
\end{tabular}

Price of Pseudomonas fluorescens =Rs. 150/kg. Recommended for bacterial blight in Pomegranate @ 7.5kg/ha.

Area Under Pomegranate: 2298 ha, Area covered (ha) 110 

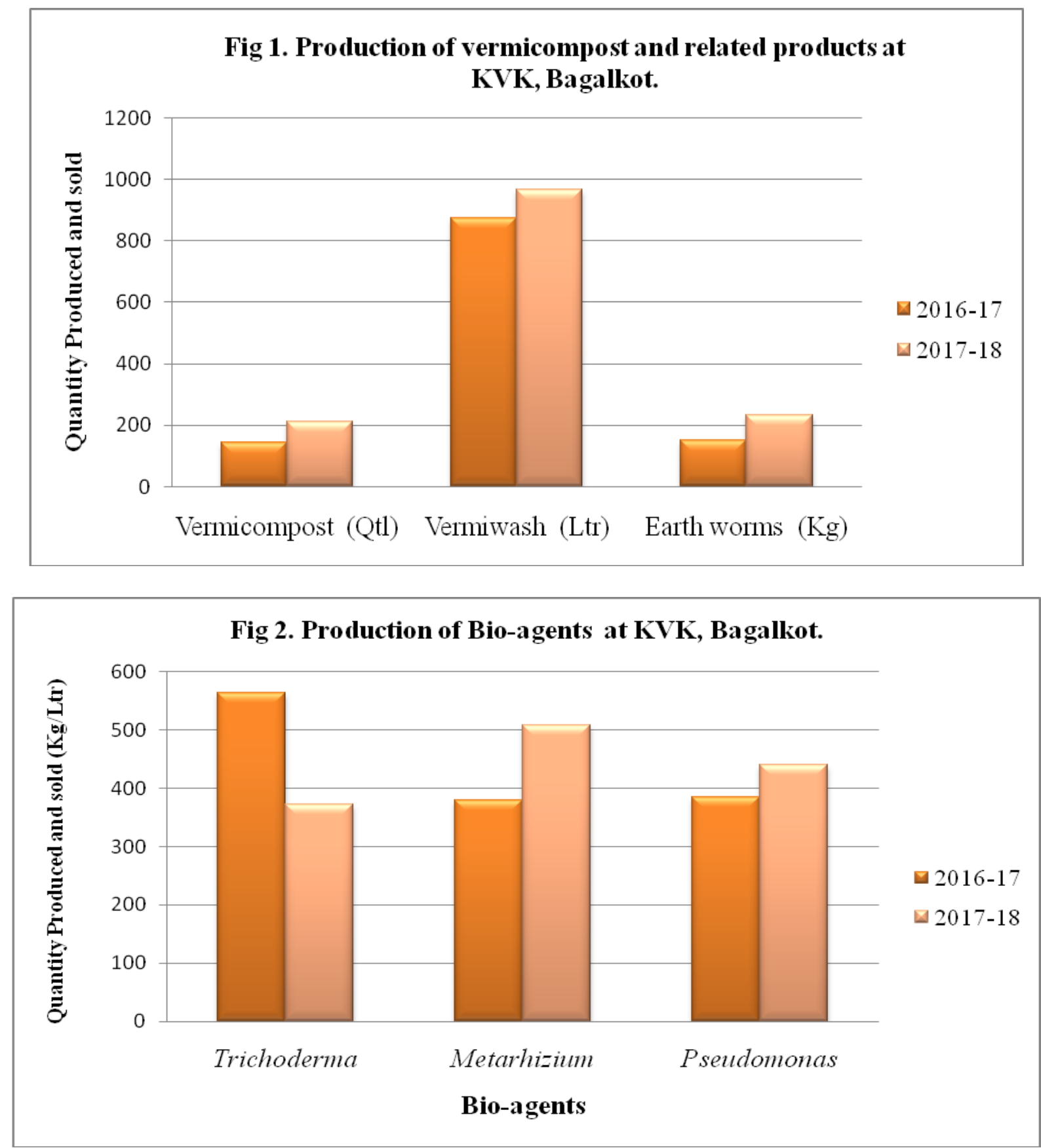

$30000 \mathrm{~kg}$ become $60,0000 \mathrm{kgs}$ in 8 months and $60,000 \mathrm{kgs}$ in another 4 months 1200000 $\mathrm{kg} /$ year. $=150 \mathrm{~kg}$ become $1200000 \mathrm{~kg}$

During 2017-18: - 233kg earth worm become $1864000 \mathrm{~kg}$ in 12 months.

Hence, totally (2016-17 and 2017-18):$1200000+1864000=3064000 \mathrm{~kg}$ of worms are produced with the spread of this technology apart from training. If they eat around 50 per cent of their body weight $=1532000 \mathrm{~kg}$ of the trash has been converted into vermicompost

About $936 \mathrm{~kg}$ of Trichoderma has been produced and sold by KVK, Bagalkot introducing the concept of seed treatment and soil application to overcome seed borne 
diseases and $887 \mathrm{~kg}$ Metarhizium has been produced and sold to farmers by control of Root grub in different crops. And $825 \mathrm{~kg}$ of Pesudomonas has been produced and sold to farmers by controlling bacterial disease of Pomegranate and other crops.

Apart from production demonstrations and awareness through literature is also being created among the farmers.

The impact analysis of these products on the district economy was carried out at KVK Bagalkot using the secondary data and has been published in the annual report, 2017-18 (Anon. 2018).

The increasing trend in production and sale of bio-agents and vermicompost, earthworms and vermiwash indicates that organic farming is going to be the future way of agriculture. Slowly and steadily the soil health is going to gain its original composition.

The stakeholders in agriculture may be made responsible in popularizing practices of organic agriculture through various activities, more and more programmes on organic agriculture may also be planned in this direction.

A special wing in Krishi Vigyan Kendra or Other institute with outreach activities may be set up to make organic agriculture sustainable and profitable venture.

\section{References}

Anonymous, 2017. Savayav Krishige Samagra Mahiti, A publication of Institute of Organic Farming, University of Agricultural Sciences, Dharwad pp: 43. ISBN. No. 978-81-86

Anonymous, 2018. Annual Review report of Krishi Vigyan Kendra, Bagalkot, 201718.

Anonymous. 2017. Package of Practices. Published by University of Agricultural Sciences, Dharwad, Karnataka. pp: 282286.

Biradar A.P and Shaila H.M., 2006, Studies on suitability of vermipits for vermicomposting, Karnataka J. Agric. Sci., 19(2), 411-413.

Biradar A.P., 2006, 'Krishi Honnu'- a new enriched organic manure, Journal of Ecofriendly agriculture, 1(1),6-7.

Biradar A.P., P.K. Singh and R.A. Balikai, 2007, 'Krishi Honnu'- a new enriched organic manure, Journal of Ecofriendly agriculture, 2(1), 66-67.

Kumar A. 2018. Earthworm fertilization: one step towards organic farming. http://www.krishisewa.com/articles/org anic-agriculture/81-organic-wasteecycle. August 2018.

Willem J., Lubbers I.M., Vos H.M.J., Brown G.G., Deyn G.B.D. and Kees Jan. 2014. Earthworms increase plant production: A meta-analysis. Scientific Reports 4, 6365.

\section{How to cite this article:}

Mouneshwari R. Kammar, A.P. Biradar, Arjun Sulagitti and Sudha, S. 2018. Self-Sustainability of Farming Community through Promotion of Organic Agriculture: A Case Study of KVK, Bagalkot. Int.J.Curr.Microbiol.App.Sci. 7(09): 3653-3658. doi: https://doi.org/10.20546/ijcmas.2018.709.454 